\title{
Osteoporosis: a 3rd millennium disease
}

\author{
E Ippolito ${ }^{*}$, P Farsetti, D Lecce \\ From de Senectute: Age and Health Forum \\ Catanzaro, Italy. 5-7 December 2009
}

Osteoporosis is currently considered a skeletal disease characterized by a diminished resistance of bone tissue, which predisposes to a greater risk of fractures. This disease, which affects mainly postmenopausal women, is constantly increasing, especially owing to a longer lifespan; reliable epidemiological studies have reported that all over the world there are more than 200 million osteoporotic subjects. Osteoporosis is evaluated by calculating bone mineral density (BMD), analyzing bone quality, and estimating risk factors. BMD is calculated using DEXA (Dual-Energy Xray Absorptiometry), QCT (Quantitative Computed Tomography), and QUS (Quantitative Ultrasonography). The analysis of bone quality includes various factors such as microarchitecture, geometry, bone turnover, mineralization, and the properties of collagen and the extracellular matrix. The most common risk factors for osteoporosis are hereditary predisposition, sex, age, early menopause, smoking, use of corticosteroid drugs for long periods of time, malabsorption, and endocrine disorders. The orthopedic surgeon is increasingly more involved in treating so-called fragility fractures caused by osteoporosis. The sites most frequently affected by these fractures are the femoral neck, the proximal part of the humerus, the vertebrae, and the distal part of the radius. Currently, fragility fractures are often treated surgically by using devices, which allow obtaining stable internal fixation in a less resistant bone and early joint mobilization. In fact, the study of the most recent surgical devices has been oriented toward finding materials with osteoconductive and osteoinductive properties, which can be used while respecting and supporting the bone's regenerative capacity. As far as medical treatment of osteoporosis is concerned, the most widely used drugs are bisphosphonates, peptides of the parathyroid hormone, selective modulators of estrogen receptors, and strontium ranelate. At present, the researchers involved in this problem are studying new drugs which not only \footnotetext{
Department of Orthopedic Surgery, University of Rome "Tor Vergata", Rome,
} Italy treat the disease but can also be used to support the healing process of fractures in osteoporotic patients including those treated surgically, thereby enhancing the bone tissue's regenerative potential and improving its mechanical properties.

Published: 19 May 2010

doi:10.1186/1471-2318-10-S1-L11

Cite this article as: Ippolito et al:: Osteoporosis: a 3rd millennium disease. BMC Geriatrics 2010 10(Suppl 1):L11.

\section{Submit your next manuscript to BioMed Central and take full advantage of: \\ - Convenient online submission \\ - Thorough peer review \\ - No space constraints or color figure charges \\ - Immediate publication on acceptance \\ - Inclusion in PubMed, CAS, Scopus and Google Scholar \\ - Research which is freely available for redistribution \\ Submit your manuscript at www.biomedcentral.com/submit}

